\title{
Empowering Youth Volunteerism: The Importance and Global Motivating Factors \\ Mardhiyyah Sahri
}

\author{
Academy of Contemporary Islamic Studies, Universiti Teknologi MARA Shah Alam \\ Corresponding author. E-mail: mardhiyyah@salam.uitm.edu.my
}

Khairudin Murad

Faculty of Communication and Media Studies Universiti Teknologi MARA Shah Alam

Asmidar Alias

Faculty of Civil Engineering Universiti Teknologi MARA Pahang

Mohd Dasuqkhi Mohd Sirajuddin

Academy of Contemporary Islamic Studies, Universiti Teknologi MARA Shah Alam

\section{Doi:10.5901/jesr.2013.v3n7p502}

\section{Abstract}

The positive impacts that volunteerism carries are undeniable, as it does not only mould quality human capital for the nation, but through it, we are also preparing future generation to lead the country. Malaysia currently has 1.2 million university students, however, unfortunately there is a lack of recent study of the involvement of the university students in volunteerism. Realizing the importance of the involvement of the undergraduate student in volunteerism as it acts as a tool to inculcate the sense of morality in self and social responsibility towards the country, this study seeks to highlight the importance of volunteerism as a tool for educating the youth. It also analyzes a global overview of youths volunteerism with a comparison being made to the local scenario. Most importantly, factors that motivated them in volunteering are also discussed so as to provide a guideline in empowering youth volunteerism.

\section{Introduction}

Volunteerism generally can be described as the act of giving without expecting any return. Social workers get paid for their work while it might not be the case for volunteers. Volunteering can be categorised in four ways, namely: mutual aid or self-help, philanthropy or service to others, civic participation, and advocacy or campaigning (United Nations Volunteer, 2011).

A survey in the UK suggested that volunteering was worth up to 40 Billion Pounds per annum, making it the third largest contributor to the nation's Gross Domestic Product. In Canada, 7.5 million out of 24 million aged 15 or above are volunteers. Voluntarism also creates job opportunities. The volunteering activities carried out through non-profit organizations in the USA have been estimated to be equivalent to 9 million full time jobs according to Independant Sector (2001) as cited by (Maniam, 2004).

The history of voluntarism in Malaysia did not differ much from other societies. It begins with individual commitment to religious and charitable altruism. It is also a form of response towards human tragedies due to wars and political conflict as well as economic crisis (Ali, 2002).

The question is why should the focus be on youth?

According to Datuk Seri Hj. Mohamed Khaled Nordin, the Minister of Higher Education, there are currently 1.2 million students of Higher Education Institutions in Malaysia and they should be empowered to play their roles that would certainly contribute towards the development of the country. One of their roles is to build strong characters, idealism, skills and leadership qualities so as to become assets of the society. These characters could not be attained simply through hearing lectures in classes, but they should have an active participation in social activities and volunteering programs that will help mould strong characters and valuable human capital for the country (Nordin, 2011).

Sadly, the majority of people who join volunteer activities are retirees, while time and energy are the main obstacles for 
younger generations to be fully involved with volunteer activities.(Ali, 2002). Recruiting youth volunteer is becoming an important issue as their motivation and energy levels are higher, which can provide good returns (Hj Hussin \& Mohd Arshad, 2012).

\section{Importance of Youth Volunteerism}

According to Spanier \& B (2010), the principle that colleges and universities exist, first and foremost, is to educate the students. No matter how much brilliant research generated, or how many award-winning books published, and how many people being served through outreach activities, the primary mission is the education of students. Thus, there is a need to continuously find new strategies to enhance student success.

Educating the students should not be narrowly defined as to emphasis on the academic achievement per se. Volunteerism is a method to promote active learning, providing experience that will strengthen their commitment to civic participation, expand their educational experience, and better serve our communities.

In the Malaysian National Higher Education Strategic Plan :Laying The Foundation Beyond 2020 speech, the Prime Minister highlighted the question of whether the quality of our education system has moved in tandem with its growth in quantity; whether the younger generation passing through the national education system is adequately equipped to thrive in an increasingly global and competitive environment. He also emphasized on the need to have an 'education revolution' to ensure that the aspirations to instill a new performance culture in the public and private sectors is not crippled by the inability to nurture a new kind of human capital that is equal to the tasks and challenges ahead.

This is in line with the National Policy on Education 1986 which highlighted that 'higher education provides people with an opportunity to reflect on the critical, social, economic, cultural, moral and spiritual issues facing humanity'. One of the tools to inculcate pro-social behavior in the students such that they would be inclined towards social and humanity issues is through volunteerism. Thus, there is a strong need to build this human capital and volunteerism is one of the medium to build such character.

According to the United Nations Volunteer (2011), in their commonality as well as their complementarity, volunteering and social activism help promote social inclusion by providing opportunities for marginalised groups, such as poor women, to engage in participatory development processes. Volunteers serve as important reservoirs of knowledge for development programmes and can help ensure that development-related advocacy campaigns are relevant and legitimate. By participating in volunteering or social activism, or both, people can be empowered with the confidence, skills and knowledge necessary to effect change in their world.

During the academic year 2009/10, volunteering units at eight London-based universities joined forces in order to measure the impact of volunteering on university students on a) Personal development including confidence, selfdiscipline and motivation b) Development of transferable skills such as communication, problem solving, teamwork, time management and leadership skills c)Academic life such as development of understanding of course content d)Future career prospects including the creation of opportunities and influence on career choice and e)Social impact such as a sense of belonging and understanding(Konidari, 2010). Findings have shown that volunteering whilst studying at university provides opportunities for learning a wide range of different skills which in turn are useful for students' future employability, regardless of age or degree type.

Thus, it can be said that volunteerism would not only benefit the students from an increased skills portfolio but also an enriched educational experience, increased social capital and deeper socio- political awareness. It would also inculcate a sense of responsibility in giving back to the society.

\section{A Global Overview of Motivating Factors for Volunteerism}

Understanding the motivating factors for volunteerism can help in to encourage and manage volunteer participation and activities. However, it should be noted that the factors may vary according to the needs of each individual.

There are many factors that influence volunteerism among youths. A study in 2005 , highlighted that students in the United States attending different types of universities possess differing motivations for engaging in volunteering activities. Findings show that the influential factors are to enhance and enrich personal development, conform to the norms of, or establishing norms for significant others, escape from negative feelings, learn new skills and practicing underutilized abilities, express values related to altruistic beliefs (Burns. et al, 2005).

In China, a case study of the 2009 World Games volunteers showed that "participation motivation" is a high motivating factor for the youths to participate as volunteers. They do not want to miss an event that they can learn 
relevant experience and knowledge (Liao, Chang, \& Tsai, 2012). Thus, this shows that young people would be interested in volunteering if it provides an unforgettable experience that they can identify with themselves.

In the United States, in order to understand why the students volunteer and what they seek to achieve through their involvement, Holdsworth (2010) conducted a study using a mixed methods, a survey on 3083 student volunteers and an 18th in-depth biographies interview of university students showed different results. While the former cited enhancing cvs or employability as the main motivating factor, the latter showed that it is not a sufficient reason as individual orientation vary considerably with other factors such as acquiring particular skills, learning opportunities, personal values and opportunities to volunteer.

In Turkey, a study conducted on 175 youth community volunteers showed that the most important motivational factors for volunteerism is altruism, followed by affiliation and personal improvement. Recognition, by contrast is not a vital factor for them (Boz, 2007). Wheras comparatively, in Africa, a study on 50 youth community volunteers in Tazmania showed that recognition and respect is one of the main motivating factors for volunteering, apart from other factors such as wanting to make a difference, education and the desire to be a volunteer (Wijeyesekera, 2011).

In Australia, findings showed that there are no difference in what motivates the young Tasmanians as compared to others. However, their motivations may be held in different priorities to older volunteers, with more value for most young people on skill development, as well as giving something back to the community/pursuing personal interests/being with friends. (Moffatt, 2011)

Factors that hinders youth volunteers should also be taken into account. In 2009, a survey asked participants who had not yet volunteered what factors had prevented them from volunteering. The results show that the key factor was being too busy with academic work (41\%), not being able to find a volunteer role linked with their future career (34\%) and not finding any roles suitable to their course (20\%)(Konidari, 2010).

\section{Malaysia and Youth Volunteerism}

Altruism or the act of helping another without expecting any reward, is identified as one of the motivational factors for youth volunteerism in a cross-sectional survey involving 240 youth volunteers which founded significant positive relationship between both. This is in line with previous researches that had been conducted. (Hj Hussin \& Mohd Arshad, 2012).

Another factor for youth volunteerism would be self-motivation. A study conducted on 120 university students using the "Volunteers Function Inventory" (VFI) scale showed that there is a significant relationship between self motivation and youths involvement in volunteerism. (Johar, 2008). Isak (2007) had also highlighted the same factor in her study which showed that when the youths prosocial personality and self motivation increases, their involvement in would also increase.

Apart from those, friends, previous experience and aiming for merits for academic purposes were also identified as influential factors for youth volunteerism (Mohd Kasim, 2008).

Interestingly however, findings show that there are no relation between gender and race as factors that influence volunteerism (Mohd Kasim, 2008). Even more so, there are no relationship between the income of their family and their locality (Johar, 2008) or even CGPA results with volunteerism (Mohd Yasin, 2005). This shows how the act of volunteerism goes beyond personal gain for race, gender, money or intelligence.

With regards to participation in volunteerism however, according to the Malaysian Red Crescent Kapitan chapter chairman Dr Sia Tih Kong the spirit of volunteerism seems to be declining and this may be caused by the fast pace of development and modernisation, which has left many busily trying to cope with the demands' of their own daily lives(Borneo Post, 2011).

Previous studies have shown that the involvement of youths in volunteerism is only at a satisfactory level and this should be improved. According to a study done by Mohd Kasim (2008), out of 100 respondents who are university students, 96 percent of them have low involvement in community volunteerism while only 4 percent have moderate involvement.

This is consistent with a previous study in 2005 on multiracial undergraduates which showed that only $48.7 \%$ of the respondents were involved in volunteerism whereas 51.3\% of them are not involved (Ahmad Salim, 2005). Another study on 254 university students in 2005 , showed that although $77.2 \%$ of the respondents have the experience of being a volunteer, $76.4 \%$ of them have low participation with volunteerism and only 0.8 percent of them are actively involved (Mohd Yasin, 2005).

Thus, it can be said that although students have been exposed to volunteerism, the number of active volunteers 
are still low. This is unfortunate as the positive impacts that volunteerism carries are undeniable. There also need to be more recent studies of the youths involvement in volunteerism.

Ali (2002) has criticized the Malaysian public and authorities concerned with social development for not recognizing the importance of voluntary sector as a mode of social intervention for the development of Malaysia social care system. She highlighted that while the concept is popular, voluntary participation in voluntary sector is very limited and many voluntary organizations are facing a 'crisis of volunteers' as well as suffering from severe financial constraints.

Attrition of volunteers is a serious issue and it needs to be highlighted. It is worrisome to note on a study conducted in 1992 on 100 welfare voluntary organizations in Peninsular Malaysia of which the following results were obtained: 1) excluding those who have became committee members, 59 percent of the organizations said they did not have volunteers 2) the shortage of volunteers is due to the following reasons: 64 percent claimed that it was difficult to find people ready to become volunteers, 32 percent did not have confidence in volunteers, 29 percent felt that volunteers have low level of commitment and 31 percent felt that volunteers did not have clear purpose in organization. Similar findings were found in the next 1999/2000 study (Ali, 2002).

\section{Recommendations}

Having looked at the motivating factors globally, factors such as altruism, participation factor, opportunity to learn new skills, employability and recognition should be used as appealing factors for the government, voluntary organizations, teachers, parents and youths to attract new youth volunteers and to sustain existing ones.

Malaysian Prime Minister Dato' Seri Najib Tun Razak had announced that year 2013 would be declared as Year of Volunteer to instill the spirit of volunteerism amongst youth and have allocated RM100million seed money for IM4U volunteer program (The Star, 2012)). He also announced that 2013 will be declared the year of Volunteerism to further instill the spirit of volunteerism in youth. This step and the government promotional activities of volunteerism are most welcomed in order to empower the youths in giving back to the society.

The IM4U volunteer program is a good initiative by the government to rejuvenate the spirit of the youths in giving back to the society. Under the initiative, an RM130 million fund called the Dana Sukarelawan 1Malaysia (DRE1M) provides financial support for youth to carry out volunteer activities that are aimed at helping targeted communities and social groups. The website also provides information as to the list of voluntary organizations, latest volunteering events and activities as well as it helps to register new volunteers online (IM4U, 2013).

Be that as it may, promotion as to the IM4U volunteer program alone is not sufficient. Apart from encouraging new youth volunteers, there must be activties made to sustain the volunteers as well. The success of the program should also be measured of its impact factor towards youth and be disseminated to the public. Funds granted for youth volunteerism projects should also be made known so as to inspire other youths to come up with their own ideas and initiatives.

Aside from government initiatives, Ali (2002) suggested that voluntary organizations should be made attractive so that it appeals to the volunteers and promotes self confidence for the organization as well. The disparity between advance and ordinary volunteer one is too wide and should be narrowed done by providing proper support for the organizations. The function of media and technology should also not be denied in making volunteerism appealing to the youths.

Moffatt (2011) opined that we should suit volunteerism with its digital age, and as such, we should embrace websites and social networking. To target young volunteer audiences, we must understand how to effectively use the digital communication media. Her study in Tasmania showed that the current lack of consistently provided web-based information and application processes and the under-use of social networking, such as Facebook, for keeping volunteers updated, is clearly showing as a disconnect with Gens $Y$ and $Z$.

Those who are in the influential circle with youths such as teachers, parents and peers should play their role as well. Suprisingly, an inspirational teacher is a more influental figure than parents in volunteerism. Parents are normally described as too busy to be involved with volunteerism (Holdsworth, 2010). Thus, teachers should enhance volunteerism spirit in their students and parents should strive to change this negative perception. Youths should also be inspirational to their other peers as well.

Having said that, several issues need to be addressed in creating young wiling volunteers as well, like reassuring their confidence through offering peer ambassadors and mentors, accessing their influencers (including schools and other educational institutions, families and peers), adapting the length or regularity of their volunteer role to address their transient time commitments, addressing their access to transport, and understanding how young people prefer to communicate - in terms of media and styles (Moffatt, 2011). 
Although there are studies on the involvement of students in volunteerism, its importance as well as influential factors, there has yet to be a study on how to analyze these and come up with a model to further enhance the spirit of volunteerism among youth in our country.

A model of which how can we utilize and encourage the volume of students that we have to be involved in volunteerism in line with the aspirations of our leaders should be created. Factors that motivates and barriers that hinders youth volunteerism activity as well as interviews with students, volunteers, volunteerism related NGOs and Higher Education Institutions Student Divison officers should be analyzed in coming up with a model of volunteerism empowerment. Building a youth volunteerism empowerment model would help in capitalizing the number of 1.2 million university students that we have into giving back to the society and to mould quality human capital for the nation. This model can be used as a reference for the Ministry of Higher Education as well as Higher Education Institutions and volunteerism related NGOs.

\section{Conclusion}

Motivating factors that had been discussed should be taken into account in enhancing youth participation in volunteerism. It is important to not only to know the factors, but also to know the needs and expectations of the youths in volunteerism. What is also equally important is to have sustainable volunteers. Thus, aside from the fact that everyone should play their role in enhancing youth volunteerism, a youth volunteerism empowerment model should also be created.

\section{Acknowledgement}

Thank you to Academy of Contemporary Islamic Studies (ACIS) and Universiti Teknologi MARA for their support and encouragement. Our full gratitude to the Ministry of Education for enabling this research under the RAGS research grant to encourage and empower more youth volunteers for the nation.

\section{References}

Ahmad Salim, A.-H. (2005). Penglibatan mahasiswa dalam aktiviti kesukarelawanan: satu kajian kes di Fakulti Ekologi Manusia UPM. Universiti Putra Malaysia.

Alam Faizli, A. (2012, August). The Malaysian Insider. Retrieved October 10th, 2012, from The Malaysian Insider: http://www.themalaysianinsider.com/litee/sideviews/article/education-volunteerism-via-teach- for-the-needs-anas-alam-faizli/

Ali, H. (2002). Volunteerism and the Development of Malaysian Social Care System. International Council on Social Welfare , 101-109.

Borneo Post. (2011, November 6). Spirit of Volunteerism Declining. Retrieved from Borneo Post Online: http://www.theborneopost.com /2011/11/06/\%e2\%80\%98spirit-of-volunteerism-declining\%e2\%80\%99/\#ixzz29cNCvQBa

Boz, I. (2007). Factors influencing the motivation of turkey's communitiy volunteers. Nonprofit and Voluntary Sector Quarterly .

Brewis, G., Russell, J., \& Holdsworth, C. (2010). Bursting the Bubble: Students, Volunteering and the Community Research Summary. Institute for Volunteering Research.

Burns, D. J., Toncar, M., Reid, J., Anderson, C., Wlells, C., Fawcett, J., et al. (2005). Volunteering: A Comparison of the Motivations of Collegiate Students Attending Different Types of Institution. The Journal of Volunteer Administration , 32-40.

Hj Hussin, Z., \& Mohd Arshad, M. R. (2012). Altruism as Motivational Factors toward Volunteerism among Youth in Petaling Jaya Selangor. IPEDR , 225-229.

Holdsworth, C. (2010). Why Volunteer? Understanding Motivations for Student Volunteering. British Journal of Educational Studies , 421-437.

IM4U. (2013). IM4U. Retrieved May 12, 2013, from 1M4U: http://www.1m4youth.com.my/

Isak, S. (2007). Pengaruh ciri personaliti prososial dan motivasi terhadap penglibatan aktiviti kesukarelawanan di kalangan mahasiswa UPM. Universiti Putra Malaysia.

Johar, N. (2008). Motivasi diri dan tahap penglibatan melakukan kerja-kerja kesukarelawanan di kalangan mahasiswa UPM. Universiti Putra Malaysia.

Konidari, S. (2010). Reach Bulletin. Retrieved 2013 йил 15-May from Reach London Metropolitan University: reach.londonmet.ac.uk

Liao, L.-C. C., Chang, H.-M., \& Tsai, T.-F. (2012). Study of volunteers' participation motivation, work satisfaction and perceived value in mega-sports event: case of the 2009 world games. International Conference on Innovation and Information Management. IPCSIT.

Liddie, K. M. (2010). What motivates people to volunteer: A case study using coastal cleanup day in san luis obispo california. California Polytechnic State University.

Maniam, V. A. (2004). Volunteerism for Youth Development. INTI Journal , 306-317.

Moffatt, L. (2011). Engaging young people in volunteering: what works in Tasmania? Volunteering Tasmania.

Mohd Kasim, M. (2008). Penglibatan mahasiswa institusi pengajian tinggi swasta dalam kerja kesukarelawanan komuniti: satu kajian 
kes di kalangan mahasiswa UNITEN dan KLIU Kolej. Universiti Putra Malaysia.

Mohd Yasin, F. N. (2005). Pengetahuan dan penglibatan dalam kerja-kerja kesukarelawanan komuniti: satu kajian kes di kalangan mahasiswa UPM. Universiti Putra Malaysia.

National Higher Education Strategic Plan: Laying the Foundation Beyond 2020.

Nordin, K. (2011, September 29th). Mahasiswa: Gerak untuk Malaysia. Utusan Malaysia.

Spanier, \& B, G. (2010). Creating Adaptable Universities. Innovate Higher Education , 91-99.

Tansey, L., \& Gonzalez-Perez, M.-A. (2006). University Platform and Student Volunteering: Harnessing Student Civic Engagement through Volunteering. Community Knowledge Initiative National University of Ireland .

The Star. (2012, July 16). RM100 million fund for iM4U. The Star.

United Nations Volunteer. (2011). State of the World's Volunteerism Report. United Nations.

Wijeyesekera, D. (2011). The State of Youth Volunteering in Africa. International Forum on Development Service.

Wilson, J., \& Musick, M. (1999). The Effects of Volunteering on the Volunteer. Law and Contemporary Problems. 